\title{
PEMODELAN MATEMATIKA TERHADAP PENYEBARAN VIRUS KOMPUTER DENGAN PROBABILITAS KEKEBALAN
}

\author{
Neni Nur Laili Ersela Zain ${ }^{*}$ (iD), Pardomuan Robinson Sihombing2 ${ }^{2}$ \\ 1Program Studi Matematika Universitas Airlangga, Indonesia \\ 2Badan Pusat Statistik, Indonesia \\ ${ }^{1 *}$ neni.nur.laili-2014@fst.unair.ac.id , ${ }^{2}$ robinson@bps.go.id
}

Received: July 21, 2021

Revised: August 28, 2021

Accepted: September 6, 2021

\begin{abstract}
:
The increase in the number of computer viruses can be modeled with a mathematical model of the spread of SEIR type of diseases with immunity probability. This study aims to model the pattern of the spread of computer viruses. The method used in this research is the analytical method with the probability of mathematical immunity. Based on the analysis of the model, two equilibrium points free from disease E1 and endemic equilibrium points E2 were obtained. The existence and local stability of the equilibrium point depends on the basic reproduction number RO. Equilibrium points E1 and E2 tend to be locally stable because $R 0<1$ which means there is no spread of disease. While the numerical simulation results shown that the size of the probability of immunity will affect compartment $R$ and the minimum size of a new computer and the spread of computer viruses will affect compartments $S$ and $E$ on the graph of the simulation results. The conclusion obtained by the immune model SEIR successfully shows that increasing the probability of immunity significantly affects the increase in the number of computer hygiene after being exposed to a virus.
\end{abstract}

Keywords: virus, model pSEIR, kestabilan, simulasi.

How to Cite: Zain, N. N. L., \& Sihombing, P. R.. (2021). Pemodelan Matematika Terhadap Penyebaran Virus Komputer dengan Probabilitas Kekebalan. Alifmatika: Jurnal Pendidikan dan Pembelajaran Matematika, 3(2), 122-132. https://doi.org/10.35316/alifmatika.2021.v3i2.122-132

\section{PENDAHULUAN}

Perkembangan internet menimbulkan beberapa tantangan dan salah satu tantangannya adalah keamanan cyber. Sebuah sistem pertahanan cyber harus dapat diandalkan, oleh karena itu dibutuhkan usaha perlindungan terhadap informasi penting yang tersimpan pada sistem dan informasi yang transit (keluar masuk). Untuk mencapai tujuan ini, perlu adanya hal-hal yang harus dimengerti dan dipelajari secara mendasar tentang berbagai bentuk dari entitas jahat seperti virus, trojan, dan worm, serta yang lainnya pada skala yang lebih luas. Selain itu juga perlu adanya hal-hal yang harus dimengerti tentang bagaimana mereka menyebar sepanjang jaringan komputer (Khan, 2014). Virus komputer sendiri merupakan kode atau program berbahaya yang dapat mereplika dirinya dan menyebar melalui kabel atau tanpa kabel dalam sebuah jaringan. Virus komputer telah menjadi ancaman besar dalam pekerjaan dan kehidupan sehari-hari, ditambah lagi dengan adanya Internet of Things (IoT), ancaman ini akan menjadi semakin serius. Maka diperlukan suatu kemampuan untuk memahami bagaimana

Content from this work may be used under the terms of the Creative Commons AttributionShareAlike 4.0 International License that allows others to share the work with an acknowledgment of the work's authorship and initial publication in this journal. 
virus komputer tersebut menyebar, sehingga dapat mengatasinya masalah penyebarannya. Untuk mencapai tujuan ini, dan mengingat fakta bahwa penyebaran virus antar komputer menyerupai penyebaran virus secara biologis dalam suatu populasi, maka pemodelan yang dinamis untuk dapat menggambarkan penyebaran virus komputer di seluruh internet dengan memodifikasi model epidemi secara tepat sangat mendukung untuk dilakukan (Yang, 2012). Hal yang sama juga dilakukan oleh Pemungkas dkk (2019) dalam mengembangan model epidemik untuk penyebaran virus pada jaringan komputer.

Pada umumnya model epidemiologi yang ada adalah versi modifikasi dari model SIR yang di pelopori oleh Kermack dan Kendrick (1927). Model SIR merupakan singkatan dari susceptible (S), infected (I) dan recovered (R). Contoh pengembangan model SIR adalah penelitian yang dilakukan oleh Hethcote (1976) yang mengusulkan model SIR dengan asumsi bahwa jumlah penduduk adalah tetap. Akan tetapi pada kenyataannya populasi akan berubah seiring dengan waktu. Dengan demikian, model ini kemudian diperbaiki oleh Diekmann dan Heersterbeek (2000) dengan asumsi bahwa : ukuran populasi berubah sesuai dengan tren demografis eksponensial, individu yang terinfeksi tidak dapat bereproduksi dan individu memperoleh kekebalan permanen terhadap infeksi lebih kuat ketika dikeluarkan dari kelas yang terinfeksi (Juhari, 2015). Ketika model SIR klasik diimplementasikan pada jaringan kecil, ternyata model SIR tidak mampu menangkap sifat realistis dari perambatan virus dalam jaringan komputer. Sehingga diperlukan pertimbangan jaringan bebas skala yang lebih realistis. Kemudian pembenaran matematis mengikuti pengenalan model SEIRS telah membahas kondisi matematika untuk keseimbangan bebas infeksi dengan hasil validasi aspek skalabilitas dari model yang diusulkan dan harapan membandingkannya dengan SEIRS klasik model (Khan, 2014). Model ini secara umum identik dengan penurunan model SIR, hanya mengalami penambahan sebuah variabel exposed (E), yaitu individu yang telah terpapar oleh penyakit namun belum sepenuhnya terinfeksi. Dalam hal ini populasi dibagi menjadi 4 kelompok, yaitu susceptible (S), exposed (E), infected (I), dan recovered (R).

Melalui beberapa penelitian kestabilan model SEIR telah diuji seperti pada penelitian yang dilakukan oleh Safi dan Garba (2012) dimana hasil akhir penelitian menunjukkan bahwa; i) Model SEIR memiliki DFE (disease-free-equilibrium) yang stabil secara lokal untuk setiap nomor reproduksi yang kurang dari satu, ii) Model DFE pada SEIR terbukti bahwa stabil asimtotik secara umum saat $\mathrm{R} 0<1$, iii) Model pada SEIR persisten dengan seragam pada D, jika dan hanya jika R0 $>1$, iv) Titik setimbang endemik pada modifikasi model SEIR dengan parameter zeta $=0$, dapat dinyatakan bahwa secara umum bersifat stabil asimtotik. Model SEIR sendiri telah banyak digunakan dalam berbagai penelitian, seperti pada penelitian yang dilakukan oleh Etbaigha, dkk (2018), Sihotang (2019), dan Godio, dkk (2020).

Berdasarkan beberapa kelemahan model SIR yang telah disebutkan di atas, peneliti akan memfokuskan pada model SEIR untuk dikaji lebih lanjut. Hal ini berdasarkan asumsi komputer yang telah sembuh dari terinveksi virus sudah mempunyai proteksi untuk tidak terinfeksi lagi.

Alifmatika: Jurnal Pendidikan dan Pembelajaran Matematika, Desember 2021, Vol. 3, No. 2 


\section{METODE PENELITIAN}

Penelitian ini dilakukan dengan menggunakan metode penelitian kepustakaan atau studi literatur. Adapun metode yang digunakan adalah metode analitik. Langkah-langkah yang dilakukan dalam untuk menyelesaikan Pemodelan Matematika terhadap penyebaran virus komputer dengan probabilitas kekebalan menggunakan model pSEIR dapat diliat pada bagan berikut ini :

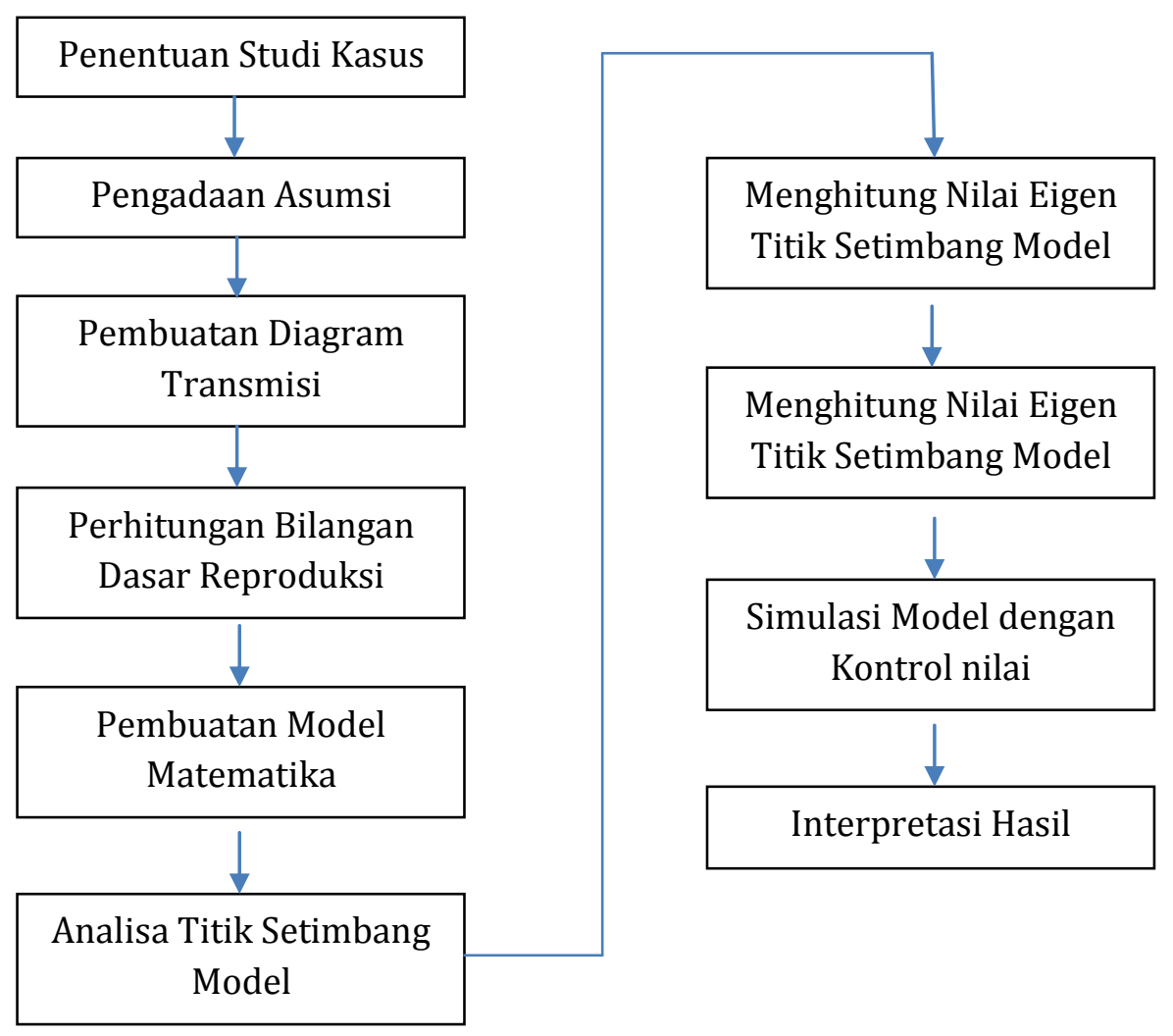

Gambar 1. Bagan Penelitian

Pada Gambar 1 terlihat bahwa penelitian diawali dengan penentuan studi kasus, lalu diuji asumsi pada data yang digunakan. Selanjutnya dilakukan pembuatan diagran dan pembuatan bilangan dasar reproduksi dan dibuat sebuah model matematika. Langka selanjutnya adalah aanlisi titik seimbang sehingag didapa egen titik keseimbangan untuk dilakukan simulasi model. Dan langkah akhir adalah intrepetasi hasil simulasi.

\section{Matriks}

Dalam pembentukan analisia model titik setimbang akan ditentukan nilai eigen agar tercapai titik seimbang. Nilai eigen tersebut di dapat dari matrik yang dibentuk sehingga langkah awal perlu didefenisikan terkait matriks untuk mendapatkan nilai eigen.

Alifmatika: Jurnal Pendidikan dan Pembelajaran Matematika, Desember 2021, Vol. 3, No. 2 
Definisi 1 Misalkan A adalah matriks $\mathrm{n}$ x $\mathrm{n}$ dengan komponen bilangan real. Vector tak nol x di dalam $\mathbb{R}^{\mathrm{n}}$ atau $\mathbb{C}^{\mathrm{n}}$ disebut vektor eigen dari $\mathrm{A}$, jika Ax dapat dinyatakan sebagai kelipatan scalar dari $\mathrm{x}$, yakni:

$\mathrm{Ax}=\lambda \mathrm{x}$

Untuk suatu skalar $\lambda$ dinamakan nilai eigen dari A dan x dikatakan vektor eigen yang bersesuaian dengan $\lambda$.

Teorema 1 Jika A adalah matriks n x n, dan $\lambda$ adalah nilai eigen bernilai real dari A, maka pernyataan berikut ekuivalen (Anton, 2005) :

1. Nilai eigen dari A adalah $\lambda$.

2. Sistem persamaan $(\lambda I-A) x=0$ mempunyai pemecahan tak trivial.

3. Ada vektor tak nol $\mathrm{x}$ di dalam $\mathbb{R}^{\mathrm{n}}$ sehingga $\mathrm{Ax}=\lambda \mathrm{x}$.

4. Pemecahan dari persamaan karakteristik $\operatorname{det}(\lambda \mathrm{I}-\mathrm{A}) \mathrm{x}=0$ adalah $\lambda$.

Matriks Jacobian adalah matriks yang elemen-elemennya merupakan turunan parsial pertama dari beberapa fungsi(Perko, 2001).

Definisi 2 Matriks jacobian dari sistem persamaan:

adalah

$$
\begin{aligned}
& y_{1}=f_{1}\left(x_{1}, x_{2}, x_{3}, \ldots, x_{n}\right), \\
& y_{2}=f_{2}\left(x_{1}, x_{2}, x_{3}, \ldots, x_{n}\right), \\
& y_{3}=f_{3}\left(x_{1}, x_{2}, x_{3}, \ldots, x_{n}\right), \\
& \vdots \\
& y_{n}=f_{n}\left(x_{1}, x_{2}, x_{3}, \ldots, x_{n}\right),
\end{aligned}
$$

$$
\left(\begin{array}{ccccc}
\frac{\partial \mathrm{y}_{1}}{\partial \mathrm{x}_{1}} & \frac{\partial \mathrm{y}_{1}}{\partial \mathrm{x}_{2}} & \frac{\partial \mathrm{y}_{1}}{\partial \mathrm{x}_{3}} & \ldots & \frac{\partial \mathrm{y}_{1}}{\partial \mathrm{x}_{\mathrm{n}}} \\
\frac{\partial \mathrm{y}_{2}}{\partial \mathrm{x}_{1}} & \frac{\partial \mathrm{y}_{2}}{\partial \mathrm{x}_{2}} & \frac{\partial \mathrm{y}_{2}}{\partial \mathrm{x}_{3}} & \ldots & \frac{\partial \mathrm{y}_{2}}{\partial \mathrm{x}_{\mathrm{n}}} \\
\frac{\partial \mathrm{y}_{3}}{\partial \mathrm{x}_{1}} & \frac{\partial \mathrm{y}_{3}}{\partial \mathrm{x}_{2}} & \frac{\partial \mathrm{y}_{3}}{\partial \mathrm{x}_{3}} & \ldots & \frac{\partial \mathrm{y}_{1}}{\partial \mathrm{x}_{\mathrm{n}}} \\
\vdots & \vdots & \vdots & \ddots & \vdots \\
\frac{\partial \mathrm{y}_{\mathrm{n}}}{\partial \mathrm{x}_{1}} & \frac{\partial \mathrm{y}_{\mathrm{n}}}{\partial \mathrm{x}_{2}} & \frac{\partial \mathrm{y}_{\mathrm{n}}}{\partial \mathrm{x}_{3}} & \ldots & \frac{\partial \mathrm{y}_{\mathrm{n}}}{\partial \mathrm{x}_{\mathrm{n}}}
\end{array}\right)
$$

\section{Sistem Persamaan Deferensial}

Definisi 2 Sistem persamaan diferensial orde satu dalam tiga persamaan disebut sebagai sistem autonomous jika dapat ditulis kedalam bentuk (Jones \& Sleeman, 2003):

$$
\begin{aligned}
& \frac{d x_{1}}{d t}=f_{1}\left(x_{1}, x_{2}, x_{3}\right) \\
& \frac{d x_{2}}{d t}=f_{2}\left(x_{1}, x_{2}, x_{3}\right) \\
& \frac{d x_{3}}{d t}=f_{3}\left(x_{1}, x_{2}, x_{3}\right)
\end{aligned}
$$

Alifmatika: Jurnal Pendidikan dan Pembelajaran Matematika, Desember 2021, Vol. 3, No. 2 
dengan fungsi $\mathrm{f}_{1}, \mathrm{f}_{2}$, dan $\mathrm{f}_{3}$ atas variabel $\mathrm{x}_{1}, \mathrm{x}_{2}, \mathrm{x}_{3}$ tidak tergantung pada waktu $(\mathrm{t})$ atau dengan kata lain variabel t tidak muncul secara eksplisit.

Definisi 3 Pandang persamaan diferensial yang autonomous $\frac{d x}{d t}=f(x)$. Titik $\bar{x}$ dikatakan titik setimbang jika memenuhi $\mathrm{f}(\overline{\mathrm{x}})=0$.

\section{Kestabilan Sistem Linear}

Definisi 4 Sistem linear $\dot{\mathrm{x}}(\mathrm{t})=\mathrm{Ax}(\mathrm{t})$ dikatakan stabil asimtotis jika

$$
\lim _{\mathrm{t} \rightarrow \infty} \mathrm{x}(\mathrm{t})=0
$$

dengan $x(t)$ adalah solusi dari sistem tersebut.

Teorema 2 Sistem linear $\dot{\mathrm{x}}(\mathrm{t})=\mathrm{Ax}(\mathrm{t})$ adalah stabil asimtotis jika dan hanya jika semua nilai eigen dari $A$, yakni $\lambda_{i}(A)$, dengan $i=1,2,3, \ldots, k \leq n$ mempunyai bagian real yang negative dan dinotasikan sebagai $\operatorname{Re}\left(\lambda_{i}(A)\right)<0 \quad$ (Olsder \& Woude, 2003).

\section{HASIL DAN PEMBAHASAN}

Dalam penelitian ini menggunakan data simulasi. Terdapat empat populasi yang digunakan dalam peneltian dengan rincian sebagai berikut:

1. Populasi komputer yang rentan terkena virus (S)

2. Populasi komputer yang telah terkena virus namun tidak bisa menularkan (E)

3. Populasi komputer yang terkena virus dan dapat menularkan (I)

4. Populasi komputer yang telah bersih dari virus (R)

Adapun parameter-parameter yang digunakan dalam model adalah :

$\beta=$ laju penambahan komputer baru

$\gamma=$ laju penyebaran virus komputer

$\mu=$ laju kerusakan komputer

$\omega=$ laju komputer yang terinfeksi virus

$\alpha=$ laju komputer yang bersih

$\rho=$ probabilitas kekebalan virus

Berikut adalah diagram transmisi dari model matematika penyebaran virus komputer dengan probabilitas kekebalan:

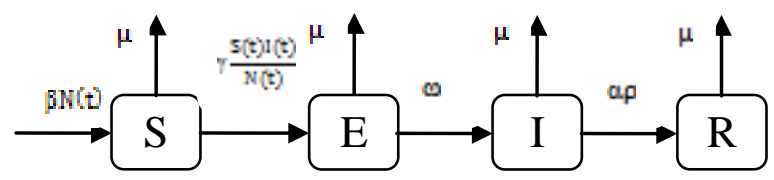

Gambar 2 Diagram Transmisi Model Penyebaran Virus Komputer dengan Probabilitas Kekebalan 
Berdasarkan diagram transmisi tersebut maka didapatkan model matematika penyebaran virus komputer dengan probabilitas kekebalan sebagai berikut :

$$
\begin{aligned}
& \frac{d S(t)}{d t}=\beta N(t)-\gamma \frac{S(t) I(t)}{N(t)}-\mu S(t) \\
& \frac{d E(t)}{d t}=\gamma \frac{S(t) I(t)}{N(t)}-(\mu+\omega) E(t) \\
& \frac{d I(t)}{d t}=\omega E(t)-(\mu+\alpha \rho) I(t) \\
& \frac{d R(t)}{d t}=\rho \alpha I(t)-\mu R(t)
\end{aligned}
$$

dengan $N(t)$ jumlah total keseluruhan populasi, $N(t)=S(t)+E(t)+I(t)+R(t)$.

\section{Titik Setimbang Model}

Berdasarkan Definisi 3, model matematika penyebaran virus komputer dengan probabilitas kekebalan akan memiliki titik setimbang jika memenuhi $\frac{d S(t)}{d t}=\frac{d E(t)}{d t}=\frac{d I(t)}{d t}=\frac{d R(t)}{d t}=0$. Selanjutnya dari hasil perhitungan didapatkan dua jenis titik setimbang yaitu titik setimbang bebas virus dan titik setimbang terjangkit virus.

\subsection{Titik Setimbang Bebas Virus}

Titik setimbang bebas virus terjadi jika tidak ada komputer yang terkena virus. Sehingga nilai $\mathbf{E}=\mathbf{I}=\mathbf{0}$ dan $\mathbf{S} \neq \mathbf{R} \neq \mathbf{0}$. Misalkan $\mathrm{E}_{1}=\left(\mathrm{S}(\mathrm{t})^{*}, \mathrm{E}(\mathrm{t}), \mathrm{I}(\mathrm{t}), \mathrm{R}(\mathrm{t})^{*}\right)$, dengan $\mathrm{E}_{1}$ adalah titik setimbang bebas virus. Perhitungannya sebagai berikut :

Ketika $\frac{d R(t)}{d t}=0$, maka

$\frac{\mathrm{dR}(\mathrm{t})}{\mathrm{dt}}=0=\rho \alpha \mathrm{I}(\mathrm{t})-\mu \mathrm{R}(\mathrm{t})$

$\mu R(t)=\rho \alpha I(t)$

$\mathbf{R}(\mathbf{t})^{*}=\frac{\rho \alpha I(t)}{\mu}=0$

Ketika $\frac{\mathrm{ds}(\mathrm{t})}{\mathrm{dt}}=0$, maka

$\frac{\mathrm{dS}(\mathrm{t})}{\mathrm{dt}}=0=\beta \mathrm{N}(\mathrm{t})-\gamma \frac{\mathrm{S}(\mathrm{t}) \mathrm{I}(\mathrm{t})}{\mathrm{N}(\mathrm{t})}-\mu \mathrm{S}(\mathrm{t})$

$\gamma \frac{\mathrm{S}(\mathrm{t}) \mathrm{I}(\mathrm{t})}{\mathrm{N}(\mathrm{t})}+\mu \mathrm{S}(\mathrm{t})=\beta \mathrm{N}(\mathrm{t})$

Alifmatika: Jurnal Pendidikan dan Pembelajaran Matematika, Desember 2021, Vol. 3, No. 2 
$\mathrm{S}(\mathrm{t})\left(\gamma \frac{\mathrm{I}(\mathrm{t})}{\mathrm{N}(\mathrm{t})}+\mu\right)=\beta \mathrm{N}(\mathrm{t})$

Substitusikan nilai I(t) dan didapatkan

$\mu \mathrm{S}(\mathrm{t})=\beta \mathrm{N}(\mathrm{t})$

$\mathbf{S}(\mathbf{t})^{*}=\frac{\beta \mathrm{N}(\mathrm{t})}{\mu}$

Didapatkan titik setimbang bebas virus $\mathrm{E}_{1}=\left(\frac{\beta \mathrm{N}(\mathrm{t})}{\mu}, 0,0,0\right)$

\subsection{Titik Setimbang Terjangkit Virus}

Titik setimbang bebas virus terjadi jika terdapat komputer yang terkena virus. Sehingga nilai $\mathbf{S} \neq \mathbf{E} \neq \mathbf{I} \neq \mathbf{R} \neq \mathbf{0}$. Misalkan $\mathrm{E}_{2}=\left(\mathrm{S}(\mathrm{t})^{*}, \mathrm{E}(\mathrm{t})^{*}, \mathrm{I}(\mathrm{t})^{*}, \mathrm{R}(\mathrm{t})^{*}\right)$, dengan $E_{2}$ adalah titik setimbang terjangkit virus, dengan menggunakan perhitungan yang sama seperti 3.2.1 maka akan didapatkan :

$$
\begin{aligned}
& \mathbf{s}(\mathbf{t})^{*}=\frac{(\mu+\alpha \rho)(\mu+\omega) N(t)}{\gamma \omega} \\
& \mathbf{E}(\mathbf{t})^{*}=\frac{N(t)\left(\left(\alpha \rho \mu-\gamma \beta+\mu^{2}\right) \omega+\mu^{2}(\mu+\alpha \rho)\right)}{\gamma(\mu+\omega) \omega} \\
& \mathbf{I}(\mathbf{t})^{*}=-\frac{N(t)\left(\mu^{3}+(\alpha \rho-\omega) \mu^{2}+\alpha \rho \mu \omega-\gamma \omega \beta\right)}{\gamma(\mu+\alpha \rho)(\mu+\omega)} \\
& \mathbf{R}(\mathbf{t})^{*}=-\frac{\rho N(t)\left(\mu^{3}+(\alpha \rho-\omega) \mu^{2}+\alpha \rho \mu \omega-\gamma \omega \beta\right)}{\gamma(\mu+\alpha \rho)(\mu+\omega) \mu}
\end{aligned}
$$

\subsection{Reproduction Number (Ro)}

Melalui prosedur berikut akan didapatkan nilai Reproduction Number dari model matematika penyebaran virus komputer dengan probabilitas kekebalan :

1. Hitung titik setimbang bebas virus $\mathrm{E}_{1}$.

2. Buat matriks $\dot{X}=\left[\begin{array}{l}\hat{E} \\ \dot{I}\end{array}\right]$ dan dengan $\dot{x}=f(x)-v(x)$ pisahkan $f(x)$ dan $v(x)$.

3. Hitung $\mathrm{F}=\nabla \mathrm{f}$ dan $\mathrm{V}=\nabla \mathrm{v}$, dengan $\nabla \mathrm{f}$ adalah jacobian $\mathrm{f}(\mathrm{x})$ dan $\nabla \mathrm{v}$ adalah jacobian $\mathrm{v}(\mathrm{x})$.

4. Hitung $\mathrm{F}\left(\mathrm{E}_{1}\right)$ dan $\mathrm{V}\left(\mathrm{E}_{1}\right)$, dengan memasukkan titik setimbang bebas virus $\mathrm{E}_{1}$ kedalam $\mathrm{F}$ dan $\mathrm{V}$.

5. Hitung $\mathrm{V}^{-1}$ yang merupakan invers dari $\mathrm{V}$.

6. Hitung $\mathrm{FV}^{-1}$ kemudian cari semua nilai eigen dari $\left|\lambda \mathrm{I}-\mathrm{FV}^{-1}\right|=0$.

7. Pilih nilai eigen maksimanum yang nantinya akan menjadi Ro.

Setelah mengikuti seuruh prosedur yang ada didapatkan:

$$
\mathbf{R o}=\left(\frac{\gamma \beta \omega}{\mu(\mu+\omega)(\mu+\alpha \rho)}\right)
$$


Titik setimbang bebas virus model matematika penyebaran virus komputer dengan probabilitas kekebalan akan stabil asimtotis jika dan hanya jika memenuhi nilai ambang batas $\operatorname{Ro}=\left(\frac{\gamma(\beta \omega}{\mu(\mu+\omega)(\mu+\alpha p)}\right)$. Sehingga populasi komputer akan bebas virus jika Ro $<1$ yaitu $\left(\frac{\gamma \beta \omega}{\mu(\mu+\omega)(\mu+\alpha p)}\right)<1$.

\subsection{Analisa Kestabilan Endemik Virus}

Untuk mengetahui kestabilan titik setimbang terjangkit virus maka dilakukan perhitungan $\left|\lambda \mathrm{I}-\mathrm{J}\left(\mathrm{E}_{2}\right)\right|=0$ yang akan menghasilkan nilai eigen dari persamaan diferensial model matematika penyebaran virus komputer dengan probabilitas kekebalan. Dengan J adalah matriks jacobian dari model dan $\mathrm{E}_{2}$ adalah titik setimbang terjangkit virus. Dalam perhitungannya digunakan Maple untuk membantu dalam melakukan proses analitik yang sangat panjang yang menghasilkan 4 nilai eigen negatif yang berarti titik setimbang $\mathrm{E}_{2}$ adalah stabil asimtotik.

\subsection{Simulasi Numerik Model}

Sebagaimana dalam Khan (2014) dinyatakan bahwa dengan menurunkan nilai laju penambahan komputer baru dan laju penyebaran virus komputer, serta kontrol nilai probailitas maka didapatkan hasil simulasi dengan Maple sebagai berikut :

1. Simulasi pertama dengan $\beta=0.004, \gamma=0.006, \mu=0.006, \omega=0.15$, $\alpha=0.04, \rho=0.2(\mathrm{~S}(\mathrm{t})$ : hitam, $\mathrm{E}(\mathrm{t}):$ Kuning, $\mathrm{I}(\mathrm{t}):$ Merah, $\mathrm{R}(\mathrm{t}):$ Biru $)$.
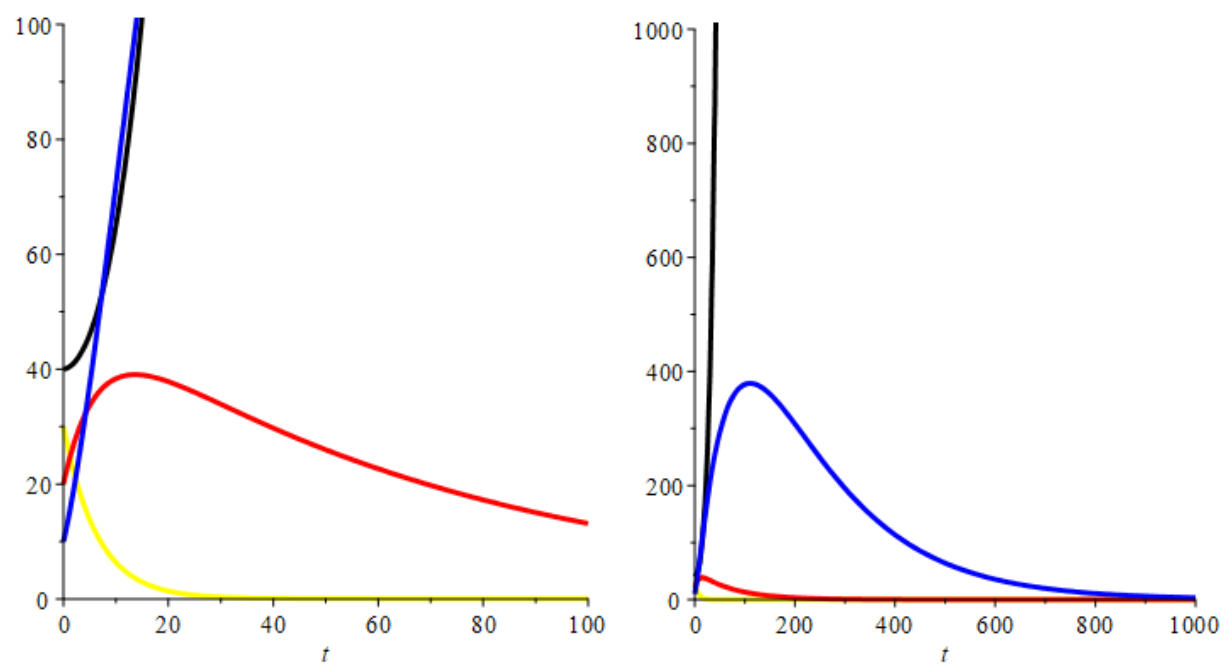

Gambar 2 Simulasi Model dengan $\rho=0.2$

Dengan menggunakan nilai parameter pada simulasi pertama didapatkan $\mathrm{R}_{0}=$ 0.2747252747 yang artinya terdapat penyebaran virus pada sistem namun bersifat non endemik. 
2. Simulasi kedua dengan $\beta=0.004, \gamma=0.006, \mu=0.006, \omega=0.15, \alpha=0.04$, $\mathrm{p}=0.5(\mathrm{~S}(\mathrm{t})$ : hitam, $\mathrm{E}(\mathrm{t})$ : Kuning, $\mathrm{I}(\mathrm{t}):$ Merah, $\mathrm{R}(\mathrm{t}):$ Biru).
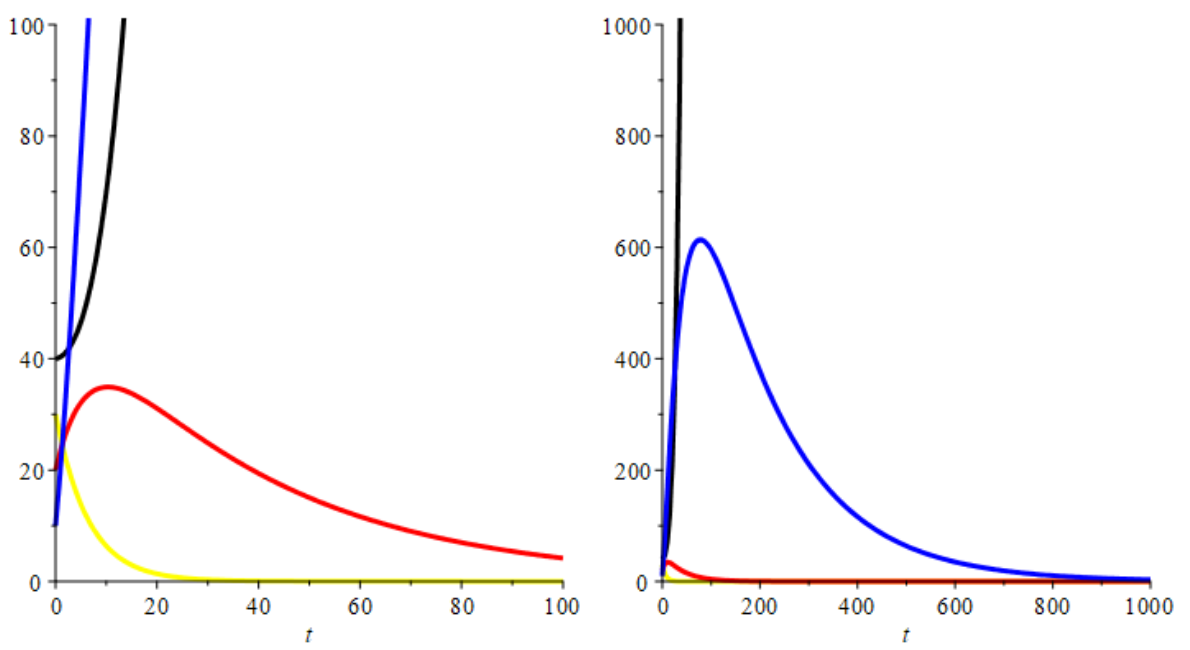

Gambar 3 Simulasi Model dengan $\rho=0.5$

Dengan menggunakan nilai parameter pada simulasi pertama didapatkan $\mathrm{R}_{0}=$ 0.1479289941.

3. Simulasi ketiga dengan $\beta=0.004, \gamma=0.006, \mu=0.006, \omega=0.15, \alpha=0.04$, $\rho=1(\mathrm{~S}(\mathrm{t})$ : hitam, $\mathrm{E}(\mathrm{t}):$ Kuning, $\mathrm{I}(\mathrm{t}):$ Merah, $\mathrm{R}(\mathrm{t}):$ Biru $)$.
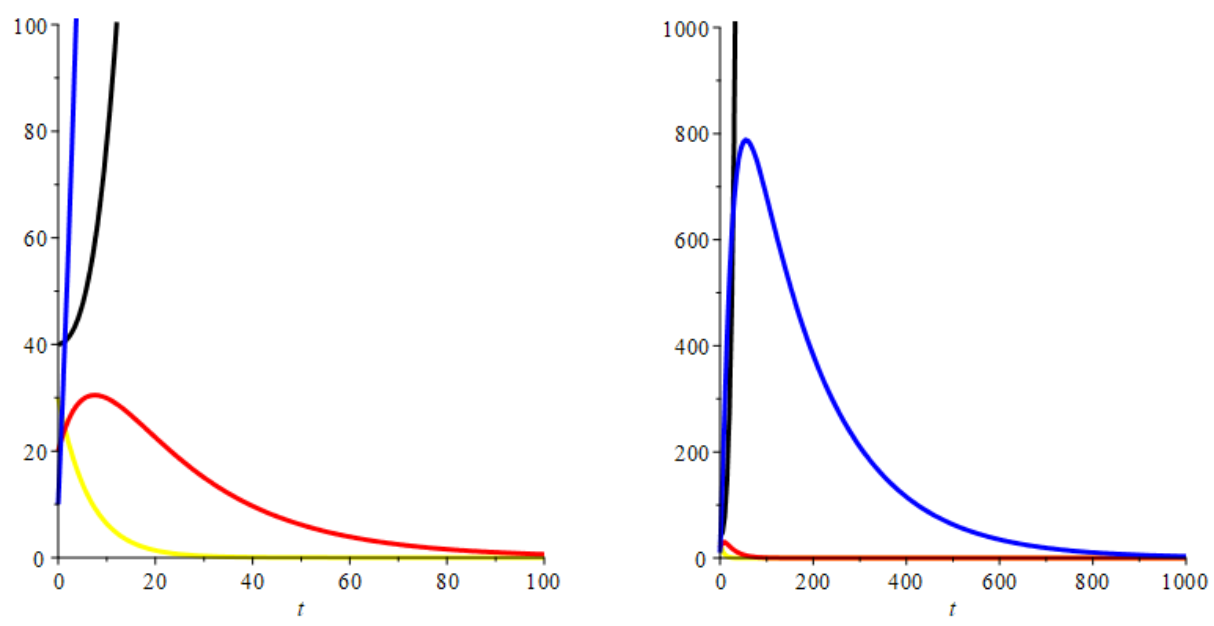

Gambar 4 Simulasi Model dengan $p=1$

Dengan menggunakan nilai parameter pada simulasi pertama didapatkan $\mathrm{R}_{0}=$ 0.08361204013 .

\subsection{Interpretasi Hasil}

Berdasarkan hasil simulasi dengan pemberian kontrol probabilitas senialai $0.2,0.5$, dan 1 . Maka dapat diketahui bahwa semakin tinggi probabilitas kekebalan komputer terhadap virus jumlah komputer yang bersih setelah terinfeksi semakin

Alifmatika: Jurnal Pendidikan dan Pembelajaran Matematika, Desember 2021, Vol. 3, No. 2 
banyak. Kemudian seiring dengan bertambahnya waktu didapatkan bahwa populasi komputer yang telah terkena virus namun tidak bisa menularkan (E) dan populasi komputer yang terkena virus dan dapat menularkan (1) mendekati nol(0) dalam hal ini akan terjadi kepunahan atau keadaan tersebut menghilang dari sistem. Hal senada juga dapat dilihat dari penelitian (Setiawan, 2017) dan (Batista, 2018).

Model pSEIRS yang diteliti oleh Khan (2014) menyebutkan bahwa komputer mengalami kerusakan(mati total) yang diakibatkan oleh virus dan kerusakan yang disebabkan oleh hal lainnya. Yaitu ketika ada komputer yang mengalami infeksi oleh virus maka komputer akan mendapatkan dua kemungkinan yaitu (i) pulih dan menjadi kebal dengan probabilitas kekebalan sementara $\rho$, atau (ii) meninggal karena infeksi dengan probabilitas $\rho$. Sedangkan dalam penelitian ini model lebih disederhanakan menjadi pSEIR dengan asumsi besar kecilnya nilai probabilitas kekebalan tetap memberikan dampak naiknya jumlah kebersihan komputer yang bergantung pada waktu, dan komputer yang telah bersih dianggap tidak akan tertular virus yang serupa dilain waktu. Adapun perbedaan yang dapat dicermati adalah $\rho S E I R$ memiliki $\mathrm{R}_{0}=0.08361204013$ untuk probabilitas kekebalan penuh $(\rho=1)$ sedangkan $\rho$ SEIRS memiliki $R_{0}=7.77$ untuk probabilitas kekebalan yang sama.

\section{KESIMPULAN}

Model matematika penyebaran virus komputer dengan probabilitas kekebalan pSEIR berhasil menunjukkan bahwa penambahan probabilitas

kekebalan berpengaruh secara signifikan terhadap naiknya jumlah kebersihan komputer setelah terkena virus. Ini berarti semakin baik antivirus dalam mengenali virus yang menjangkit akan memberikan probabilitas kekebalan yang semakin baik. Hal ini terbukti dari semakin kecilnya bilangan reproduksi dasar setelah kontrol probabilitas kekebalan dinaikkan. Kemudian untuk mendapatkan kestabilan sistem yang baik maka dilakukan perubahan dua nilai parameter yang menggambarkan bahwa dalam sistem yang diteliti nilai penambahan komputer sangat kecil dan laju penyebaran virus sangat lambat. Diharapkan untuk penelitian selanjutnya yang bertolak dengan penelitian ini untuk dapat memberikan kontrol yang lebih baik terhadap sistem dengan kemungkinan laju penularan virus yang cepat.

\section{DAFTAR PUSTAKA}

Anton, H. (2005). Elementary Linear Algebra Ninth Edition. USA: John and Sons, Inc.

Batista, F. K. (2018). A SEIR Model for Computer Virus Spreading Based on Cellular Automatic. International JointConference SOCO'17-ICEUTE'17 Leon, Proceedings, Advance in Intelligent Systems and Computing. 64. Springer International Publication. 
Diekmann, 0., \& Heesterbeek, J. (2000). Mathematical epidemiology of infectious diseases: Model building, analysis and interpretation. International Journal of Epidemiology, 303-310.

Etbaigha, F., Willms, A. R., \& Poljak, Z. (2018). An SEIR Model of Influenza A Virus Infection and Reinfection within A Farrow-to-Finish Swine Farm. PLOS One, 13(9).

Godio, A., P. F., \& Vergnano, A. (2020). SEIR Modeling of the Italian Epidemic of SARS-CoV-2 Using Computational Swarm Intelligence. International Journal of Enviromental Research and Public Health, 17.

Hethcote, H. W. (1976). Qualitative Analyses of Communicable Disease Models. Mathematical Biosciences, 28, 335-356.

Jones, D., \& Sleeman, B. ( 2003). Differential Equations and Mathematical Biology. New York: CRC Press.

Juhari. (2015). Modul Praktikum Pemrograman Komputer 2 (Pemrograman Java). Malang: UIN Malang.

Kermack, W., \& McKendrick, A. (1927). A Contribution to the Mathematical Theory of Epidemics. Proc. R. Soc, 115, 700-721.

Khan, M. (2014). A Computer Virus Propagation Model Using Delay Differential Equations with Probabilistic Contagion and Immunity. I. Vol.6, No.5. nternational Journal of Computer Network \& Communocations (IJCNC), 6(5), 111-128.

Olsder, G. J., \& Woude, J. W. (2003). Mathematical System Theory. Netherland: VVSD.

Pemungkas, P. P., Sutrisno, \& Sunarsih. (2019). Pengembangan model epidemik sira untuk penyebaran virus pada jaringan komputer. Journal of fundamental mathematics and applications (ifma), 2(1), 13-21.

Perko, L. (2001). Differential Equations and Dynamical System: Third Edition. New York: : Springer-Verlag.

Safi, M. A., \& Garba, S. M. (2012). Global Stability Analysis of SEIR Model with Holling Type II Incidence Function. . Volume 2012, Article ID 826052. . Computational and Mathematical Methods in Medicine.

Setiawan, N. F. (2017). Analisis Dan Simulasi Model Sitr Pada Penyebaran Penyakit Tuberkulosis di Kota Makassar. Makassar: Universitas Makasar.

Sihotang. (2019). Analisis Kestabilan Model SEIR Penyebaran Penyakit Campak dengan Pengaruh Imunisasi dan Vaksin MR. Jurnal Matematika, Statistika \& Komputasi, 16(1), 107-113.

Yang, L.-X. (2012). A Computer Virus Model with Graded Cure Rates. Nonlinear Analysis: Real World Applications, 14, 414-422. 